\title{
Efektivitas Poster Sebagai Media Publisitas Institusi Penerima Wajib Lapor (IPWL) Di Puskemas Kecamatan Senen
}

\author{
Dini Safitri, Rafi Adam \\ Universitas Negeri Jakarta \\ Email: dinisafitri@unj.ac.id, rafi.adam10@yahoo.com
}

\begin{abstract}
ABSTRAK
KEMENKES RI membuat sebuah program bernama Program Institusi Penerima Wajib Lapor (IPWL) di beberapa di Puskesmas DKI Jakarta. Humas Kemenkes mempublikasikan program tersebut, menggunakan poster yang pasang di puskesmas yang menjadi mitra Kementrian Kesehatan Republik Indonesia, salah satunya adalah Puskesmas Kecamatan Senen. Namun media poster tersebut kurang banyak, sehingga hanya sedikit warga yang tahu dan mendapat informasi program IPWL. Oleh karena itu penelitian ini bertujuan untuk meneliti tanggapan warga terkait poster IPWL sebagai media publikasi di Puskesmas Kecamatan Senen. Teori yang digunakan adalah tujuan publikasi yang memiliki tiga dimensi yaitu mengcounter pendapat umum, menciptakan citra positif, dan membina hubungan baik dengan publik. Pendekatan penelitian yang digunakan adalah pendekatan kuantitatif dengan jenis penelitian deskriptif. Populasi dan sampel dalam penelitian berjumlah 82 orang kepala keluarga dengan penarikan sampel sensus. Teknik analisis data yang digunakan adalah statistik deskriptif dengan menggunakan tendensi sentral mean. Nilai KMO measure of sampling dequency sebesar 0.861 dan alpha cronbach's sebesar 0.757. Hasil penelitian menunjukan, ada beberapa hal yang kurang dalam tujuan publikasi yang dilakukan oleh humas KEMENKES RI. Hal ini dibuktikan adanya dimensi mean terendah yaitu mengcounter pendapat umum. Warga merasa komunikasi yang dilakukan oleh humas KEMENKES RI sedikit kurang baik dan tidak bersifat dua arah. Dimensi tertinggi adalah membina hubungan baik dengan publik. Warga merasa humas KEMENKES RI sudah sesuai dalam menginformasikan dan membina hubungan baik dengan publik, namun warga masih merasa sosialisasi program IPWL masih kurang, untuk menyampaikan tujuan publikasinya.
\end{abstract}

Kata Kunci: Poster, Tujuan Publikasi, IPWL, Puskesmas, Kemenkes

\begin{abstract}
KEMENKES RI created a program called the Institusi Penerima Wajib Lapor (IPWL) in some of the DKI Jakarta Community Health Centers (Puskesmas). Public Relations Ministry of Health publishes the program, using posters in pairs at health centers that become partners of the Ministry of Health of the Republic of Indonesia, one of them is Puskesmas Kecamatan Senen. But the media poster is not much, so that few people who know and get information IPWL program. Therefore, this study aims to examine the responses of citizens related posters IPWL as a publication media in Health Center of Senen Sub-district. The theory used is the purpose of publication that has three dimensions that counter public opinion, create a positive image, and foster good relations with the public. The research approach used is quantitative approach with
\end{abstract}


descriptive research type. The population and sample in the study were 82 heads of households with census sampling. Data analysis technique used is descriptive statistic by using central tendency mean. KMO measure of sampling dequency equal to 0.861 and alpha cronbach's equal to 0.757 . The results showed, there are some things that are lacking in the purpose of publication conducted by public relations KEMENKES RI. It is proved that the lowest mean dimension is to counter public opinion. Residents feel the communication made by public relations KEMENKES RI slightly less good and not two-way. The highest dimension is to foster good relations with the public. Residents feel public relations KEMENKES RI is appropriate in informing and fostering good relations with the public, but residents still feel the IPWL program socialization is still lacking, to convey the purpose of publication.

Keywords: Posters, Objectives of Publication, IPWL, Puskesmas, Ministry of Health

\section{PENDAHULUAN}

Program Institusi Penerima Wajib Lapor (IPWL) merupakan program Kementrian Kesehatan (Kemenkes), salah satunya dilakukan pada beberapa Puskesmas yang ada di DKI Jakarta. Untuk mensukseskan program tersebut, Kemenkes berkerjasama dengan Kementrian Sosial, Badan Narkotika Nasional, dan Puskesmas di wilayah DKI Jakarta. Program Institusi Penerima Wajib Lapor (IPWL), dilaksanakan sejak tahun 2015. Program ini bertujuan untuk membantu pecandu narkotika dan obat-obatan terlarang dalam menjalani rehabilitasi. Namun sayangnya seperti yang dilansir dari metrotvnews.com (15/9/2017), IPWL sudah lama takberjalan. Berikut ini kutipan beritanya:

"Program Institusi Penerima Wajib Lapor (IPWL) oleh Kementerian Kesehatan di Puskesmas-Puskesmas di DKI Jakarta sudah lama tak berjalan. Salah satu faktornya adalah kekurangan dokter yang kompeten dan pasien yang berminat mendaftar sedikit. IPWL adalah program rehabilitasi yang diperuntukkan bagi pengguna dan pencandu narkotika dan obat-obatan terlarang. Program ini dihadirkan sebagai upaya pemerintah membantu pecandu menjalani rehabilitasi.Tak semua puskesmas di DKI membuka layanan IPWL. Tercatat ada 16 puskesmas di DKI yang membuka layanan ini.”

Untuk mengonfirmasikan berita di atas, peneliti melakukan wawancara dengan Kepala Sub Bagian Direktorat Masalah Penyalahgunaan Napza, Luki Hartanti Keswa di kantor Direktorat Jendral Pencegahan dan Pengendalian Penyakit (13/10/2017). Luki menuturkan bahwa program IPWL tidak hanya di DKI Jakarta, namun juga tersebar di 549 wilayah puskesmas se Indonesia. Berikut ini kutipan pernyataannya:

"Sudah ada sebanyak 549 program IPWL yang tersebar di seluruh provinsi di Indonesia. Di DKI Jakarta terdapat 16 puskesmas yang membuka program IPWL. Kementrian Kesehatan memberikan pelatihan kepada dokter-dokter dan para 
petugas puskesmas untuk dapat memberikan pelayanan IPWL yang baik di puskesmas. Sejauh ini program IPWL masih berjalan, dan saya ingin Kemenkes memberikan dana untuk membuka dan menjalani program IPWL ini di puskesmaspuskesmas di DKI Jakarta. Serta menambah tenaga dokter dan petugas agar program ini dapat berjalan lebih maksimal.”

Adanya hal yang berbeda antara tulisan di media dengan pernyataan petugas di lapangan, membuat peneliti tertarik untuk meneliti isu ini lebih lanjut. Berdasarkan hasil wawancara di atas, peneliti kemudian menemukan bahwa Puskesmas kecamatan Senen adalah puskesman yang paling banyak menerima IPLW untuk menjalankan rehabilitasi di puskesmas. Kemudian, peneliti mendatangi puskesmas kecamatan Senen untuk mendapatkan informasi lebih lanjut. Berikut ini kutipan wawancara dengan Dokter Zinnita Mutalib selaku dokter yang menangani program IPWL di Puskesmas Kecamatan Senen (16/10/2017):

"Program IPWL di puskesmas ini masih berjalan, dan ada 59 pasien yang terdaftar dalam program rehabilitasi IPWL, meskipun banyak kendala yang menghambat. Seperti kuranganya Dokter Ahli dan SDM-yang tidak menetap karena sering dipindah tugaskan ke tempat lain, sehingga tidak dapat fokus dalam menjalankan program IPWL disini. Selain itu penyuluhan yang dilakukan ke warga atau masyarakat sekitar sangat jarang sekali, dikarenakan sudah tidak mendapat anggaran yang cukup untuk mendanai acara sosisalisasi dan pembuatan media publikasi program rehabilitasi tersebut".

Selain itu, peneliti juga mewawancaai Luqmanul Hakim, petugas paramedis yang membantu Doktor Zinnita dalam menjalankan program IPWL. Berikut ini pernyataannya:

"Program ini sebeneranya sangat bagus jika SDM yang ada memadai, disini hanya dokter Zinnita dan saya yang merehabilitasi para pasien IPWL, sehingga dirasa kurang maksimal. Seharusnya di tiap puskesmas yang membuka program IPWL disediakan seorang psikolog yang dapat memberikan bimbingan konseling terhadap pasien sehingga program ini dapat berjalan maksimal sesuai tujuan awal dibuatnya program ini oleh Kementrian Kesehatan Republik Indonesia selain itu juga saya mengharapkan sosialisasi ke masyarakat ditambah misalkan dengan menempelkan poster disetiap RT, kantor RW, Kelurahan, atau Puskesmas sehingga masyarakat tahu informasi bahwa telah dibuka program IPWL di puskesmas ini”.

Peneliti juga mewawancarai warga di sekitar Puskesmas Kecamatan Senen untuk mengonfirmasi pernyataan di atas. Menurut salah satu warga, Theresia, ia sudah mengetahui bahwa puskesmas kecamatan senen memiliki program IPWL. Berikut ini kutipan pernyataannya (20/11/2017):

"Saya tahu di puskesmas sini ada program rehabilitasi narkoba karena saya sering melihat anak-anak muda sering datang ke puskesmas ini untuk rehab. Namun untuk sosialisasinya 
sendiri dari pihak puskesmas sepertinya kurang ya ke warga. Mungkin hanya melalui mulut ke mulut atau juga mungkin ada poster yang ditempel di puskesmas"

Berdasarkan paparan di atas, dapat diketahui bahwa Program IPWL masih berjalan. Salah satunya di Puskesmas Kecamatan Senen. Hanya saja, sosialisasi Program IPWL dirasakan kurang dari pihak puskesmas. Oleh karena itu, penelitii tertarik untuk meneliti lebih lanjut mengenai bagaimana tanggapan warga RT 06/ RW 01, Kelurahan Kenari, Kecamatan Senen, Jakarta Pusat terkait Poster Program Institusi Penerima Wajib Lapor (IPWL) sebagai media publikasi di Puskesmas Kecamatan Senen.

Untuk meneliti permasalahan di atas, peneliti menggunakan teori mengenai tujuan publikasi. Ada tiga dimensi yang diteliti dalam tujuan publikasi IPWL, yaitu Mengonter Pendapat Umum, Menciptakan Citra Positif, dan Membina Hubungan Baik.

Dimensi mengonter pendapat umum memiliki dua indikator yaitu memanifestasikan dua jenis sikap, yaitu positif, dan negatif. Sikap positif menyebabkan seseorang bereaksi secara menyenangkan kepada orang lain, suatu masalah, suatu kebijaksanaan atau sebuah organisasi. Sikap positif ditandai dengan anggukan kepala responden ketika membaca pesan yang disampaikan, tertawa, tersenyum, dan terkadang menggumam kata setuju, benar, dan sebaginya.

Sementara, sikap negatif memberi individu suatu opini yang tidak menyenangkan. Sikap negatif biasanya di ikuti dengan perasaan-perasaan tidak suka atau tidak puas. Sikap negatif biasanya ditandai dengan menggelengkan kepala responden membaca pesan yang disampaikan, tersenyum sinis, dan terkadang menggumamkan kata-kata tidak setuju, membantah, dan sebagainya.

Dimensi kedua menciptakan citra positif memiliki enam indikator, yaitu citra baik, itikad baik, saling pengertian, saling memercayai, saling menghargai, saling toleransi. Dan dimensi ketiga, membina hubungan baik, memiliki tiga indikator, yaitu komunikasi yang jujur, keterbukaan dan konsistensi, serta evaluasi.

Peneliti juga memiliki sejumlah kajian pustaka, yang didapatkan dari sejumlah literatur yang mendukung penellitian ini. Pertama, penelitian yang dilakukan niftah dan rahmat (2017), yang meneliti mengenai pengaruh kredibilitas konselor terhadap sikap remaja mengenai HIV/AIDS di Sukabumi. Hasil penelitian Niftah dan kawan-kawan tersebut menemukan hasil bahwa keahlian konselor dalam menyampaikan pesan tentang bahaya HIV/AIDS, membuat remaja bertambah pengetahuan dan kepercayaannya kepada konselor. 
Hasil penelitian di atas, menjadi rujukan dalam penelitian untuk membandingkan efektivitas keberhasilan sebuah pesan, namun lewat poster. Rujukan lainnya adalah penelitian yang dilakukan oleh Darwis, Hendraningrum dan Prayitno (2015) yang meneliti tentang Bahasa Publisitas Program Kegiatan Pemerintah Daerah Tingkat II Bandung. Hasil penelitian mereka menemukan hasil bahwa mayoritas bahasa yang digunakan dalam publisitas ada tiga, yaitu Bahasa Indonesia sebanyak 59.6\%, Bahasa Inggris sebanyak 20.2\% dan sisanya bahasa campuran yaitu campuran antara Bahasa Indonesia dan Bahasa Inggris. Sedangkan kata-kata yang banyak dipakai adalah tercapai sebanyak $86 \%$, belum ditindaklanjuti sebanyak $9 \%$, dan masih di proses sebanyak $5 \%$.

Dari hasil penelitian Niftah dan kawan-kawan tersebut, peneliti mendapatkan gambaran bagaimana humas pemerintah membuat bahasa publisitas. Gambaran tersebut menjadi referensi di dalam penelitian ini. Selain kedua penelitian di atas, peneliti juga mencari referensi lain dari penelitian Gani, Istiaji, dan Kusuma (2014) mengenai Perbedaan Efektivitas Leafet dan Poster Untuk Menumbuhkan Perilaku Pencegahan HIV/AIDS di Jember.

Hasil penelitian di atas menunjukan temuan bahwa ternyata leaflet lebih efektif untuk meningkatkan pengetahuan, sikap dan perilaku pencegahan HIV/AIDS dibandingkan dengan poster di kalangan mahasiswa yang mengambil jurusan non kesehatan di Universitas Jember. Hasil penelitian ini menjadikan rujukan bagi penelitian ini, yang tidak mengambil perbadingan media publikasi. Penelitian ini hanya fokus kepada poster sebagai media publikasi.

Penelitian lainnya yang pernah dilakukan di lingkungan prodi hubungan masyarakat UNJ yang menjadi rujukan dalam penelitian ini adalah penelitian yang dilakukan oleh Putri dan Larasati (2014) mengenai rendahnya partisipasi remaja usia SMA pada Kampanye Program Generasi Berencana yang dilakukan oleh BKKBN.

Hasil penelitian tersebut mendapatkan hasil bahwa rendahnya partisipasi remaja pada program kampanye tersebut harus menjadi bahan evaluasi BKKBN untuk membuat media kampanye selanjutnya. Salah satu rekomendasi penelitian adalah membuat media monitoring dan melakukan eksaminasi program dengan sekolah atau instansi terkait.

Berdasarkan hasil penelitian di atas, penelitian ini juga ingin mencari tahu mengapa program IPWL ini juga mengalami sejumlah kendala, salah satunya minimnya partisipasi warga. Sementara itu, penelitian terdahulu yang dilakukan peneliti sendiri, yang dijadikan rujukan dalam penelitian ini adalah penelitian peneliti tentang model retorika argumetasi yang dipakai oleh 
Pemerintah Jokowi pada Akun Facebook. Hasil penelitian tersebut menemukan hasil bahwa banyak ketidaksetujuan masyarakat akan beberapa kebijakan pemerintah Jokowi yang tidak popular. Namun Pemerintah Jokowi menggunakan relawan Jokowi untuk membuat sejumlah argumetasi yang mendukung kebijakan pemerintah Jokowi tersebut.

Dari penelitian hasil penelitian di atas, peneliti menggunakannya sebagai gambaran untuk penelitian ini. Penelitian ini mengenai kebijakan pemerintah yang kurang popular di masyarakat. Namun bagaimana tanggapan masyarakat sendiri, tentang masalah publikasi dalam penelitian ini. Hal itulah yang akan diteliti lebih lanjut dalam penelitian ini.

\section{METODE PENELITIAN}

Pendekatan yang peneliti gunakan dalam penelitian ini adalah pendekatan kuantitatif. Menurut Ruslan (2008: 265), penelitian kuantitatif adalah pendekatan yang menggambarkan atau menjelaskan suatu masalah yang hasilnya dapat digeneralisasikan. Proses penelitian bersifat linier, dengan langkah-langkah yang jelas, dimulai dari perumusan masalah, tujuan penelitian, konsep atau landasan teoritis, metode penelitian, teknik pengumpulan data, analisis data serta menarik kesimpulan dan saran.

Sementara itu, Nasution (2008: 24) mengatakan bahwa dalam penelitian kuantitatif peneliti lebih spesifik memusatkan perhatian kepada aspek tertentu dan menunjukkan hubungan antara berbagai variabel atau memberikan gambaran yang jelas tentang situasi sehingga bersifat deskriptif.

Sedangkan Arikunto (2010:27) mengatakan bahwa penelitian yang menggunakan pendekatan kuantitatif, dituntut menggunakan angka, mulai dari teknik pengumpulan data, sampai dengan menafsirkan data, serta memaparkan hasil penelitiannya. Selain itu, dalam menuliskan kesimpulan juga disarankan dengan disertai data yang disajikan dalam bentuk tabel, garfik, bagan, gambar ataupun tampilan data lainnya.

Jenis penelitian yang digunakan dalam penelitian ini adalah jenis penelitian deskriptif. Menurut Silalahi (2012: 28), Penelitian deskriptif mempelajari masalah-masalah masyarakat, tata cara yang berlaku dalam masyarakat, situasi tertentu tentang hubungan kegiatan, sikap, pandangan, proses yang berlangsung, dan pengaruhnya dari suatu fenomena.

Menurut Whitney dalam Nazir (2010: 63), metode deskriptif adalah metode yang digunakan dalam pencarian fakta dan yang digunakan untuk melakukan interpretasi data dengan 
tepat. Penelitian deskriptif juga mempelajari bannyak hal, antara lain adalah mempelajari masalahmasalah dalam masyarakat, tata cara yang berlaku, situasi yang berlaku dalam hubungan kegiatan, sikap, pandangan, proses yang sedang berlangsung dan pengaruh dari sebuah fenomena.

Penulis menggunakan penelitian deskriptif untuk menggambarkan sifat individu tertentu mengenai Tujuan Publikasi Humas Kementrian Kesehatan Republik Indonesia pada poster Program Institusi Penerima Wajib Lapor (IPWL) di Puskesmas Kecamatan Senen. Metode penelitian yang digunakan dalam penelitian ini adalah metode survei.

Pengertian survei menurut Prasetyo dan Jannah (2008: 143), adalah suatu metode yang digunakan dalam sebuah penelitian kuantitatif. Survei dilakukan dengan cara menggunakan pertanyaan terstruktur atau sistematis. Pertanyaan tersebut diberikan kepada banyak orang. Seluruh jawaban yang diberikan oleh banyak orang itu, kemudian dicatat oleh peneliti. Setelah itu jawaban tersebut diolah, dengan cara dimasukan kedalam sebuah software untuk kemudia dianalisis.

Dalam metode survei, pengamatan atau penyelidikan yang dilakukan juga dilaksakanakan secara kritis. Hal tersebut dilakukan untuk mendapatkan keterangan yang baik terhadap suatu persoalan yang hendak diteliti. Pengamatan seperti itu disebur dengan studi ekstensif yang kemudian dibuatkan polanya. Pola tersebut bertujuan untuk memperoleh informasi-informasi yang dibutuhkan dalam penelitian.

Waktu penelitian dilakukan pada bulan September-Desember 2017. Penelitian dilakukan di RT 06/RW 01, Kelurahan Kenari, Kecamatan Senen, Jakarta Pusat. Pada penelitian ini, peneliti menggunakan dimensi waktu penelitian cross sectional.

Menurut Hermawan (2010:89), yang dimaksud dengan dimensi waktu penelitian cross sectional, adalah suatu penelitian yang dilakukan, dikumpulkan datanya sekaligus, dan merupakan hasil sekali bidik (one snapshot) pada suatu saat tertentu. Pada penelitian tersebut, datanya dikumpulkan, dengan cara menyebarkan kuesioner.

Dalam penelitian ini yang menjadi populasi dan sampel adalah kepala keluarga RT 06/ RW 01, Kelurahan Kenari, Kecamatan Senen, Jakarta Pusat, sebanyak 82 orang dengan menggunakan teknik sampling (sensus). Berdasarkan jumlah populasi yang ada, karena jumlahnya tidak terlalu besar, sehingga ditemukan 82 orang jumlah sampel warga RT 06/ RW 01, Kelurahan Kenari, Kecamatan Senen, Jakarta Pusat. Teknik pengumpulan data dalam penelitian ini adalah dengan menyebarkan kuesioner (angket), wawancara, dan dokumentasi. 
Peneliti melakukan wawancara dengan dokter Zinnita Mutalib, petugas program rehabilitas IPWL, Luqmanul Hakim, dan perwakilan warga di sekitar puskesmas Kecamatan Senen Jl. Kramat VII No.31 RT.06 / RW.01, Kenari Senen, Jakarta Pusat.

Unit analisis dalam penelitian ini adalah individu, yaitu Warga RT 06/ RW 01, Kelurahan Kenari, Kecamatan Senen, Jakarta Pusat. Menurut Kriyantono (2010: 235), unit analisis adalah sesuatu yang akan dianalisis. Biasanya unit analisis adalah individu atau kelompok individu, sedangkan analisis isi, unit analisisnya adalah teks, pesan, atau media yang digunakan sebagai pesan.

Sedangkan unit observasi dalam penelitian ini adalah kelompok warga di sekitar Puskesmas Kecamatan Senen, Jakarta Pusat. Menurut Sugiono (2010:61), unit observasi merupakan unit sosial yang lebih besar dari unit analisis. Unit observasi adalah satuan pengamatan atau unit tempat informasi diperoleh tentang satuan unit yang akan dianalisis.

Hasil uji validitas dalam penelitian ini memperoleh nilai KMO (Kaiser Meyer Olkin) measure of sampling adequacy sebesar 0,861 yang melebihi 0,5. Maka data dalam penelitian ini dinyatakan valid. Sedangkan hasil realibilitas penelitian ini mempunya nilai cronbach's alpha sebesar 0,757 dan cronbach's alpha based on standardized items sebesar 0,759. Maka data dalam penelitian ini dinyatakan reliabel.

Skala pengukuran yang digunakan dalam penelitian ini adalah skala interval. Skala ini dipilih, agar mempermudah penulis dalam menarik kesimpulan. Adapun penjelasan skala dalam kuesioner yang disebarkan penulis, terdiri dari skala 5 yang menunjukan nilai dari Sangat Setuju (SS), skala 4 yang menunjukan nilai dari Setuju (S), skala 3 yang menunjukan nilai dari Ragu-ragu (RR), skala 2 yang menunjukan nilai dari Tidak Setuju (TS), dan skala 1 yang menunjukan nilai dari Sangat Tidak Setuju (STS).

Statistik deskriptif yang digunakan oleh peneliti dalam penelitian ini adalah tendensi sentral mean. Menurut Newman (2011: 389), yang dengan Mean atau nilai rata-rata, adalah nilai tengah dari total bilangan. Mean, juga disebut sebagai rata-rata aritmatika, merupakan ukuran yang paling banyak digunakan, dan memiliki kecenderungan memusat. Mean hanya bisa digunakan pada data yang dalam skala interval atau rasio.

Adapun keterbatasan dalam melakukan penelitian ini adalah data untuk mengetahui daerah dan jumlah pecandu narkotika tidak bisa didapatkan dari Dinas Kesehatan Republik Indonesia. 
Hal tersebut dikarenakan belum ada MOU antara Universitas Negeri Jakarta dan Dinas Kesehatan Republik Indonesia. Lokasi penelitian ditetapkan berdasarkan hasil waancara dengan narasumber yang sudah di sebutkan dibagian pendahuluan.

\section{HASIL DAN PEMBAHASAN}

Kementrian Kesehatan Republik Indonesia melakukan publikasi terhadap warga mengenai program Institusi Penerima Wajib Lapor (IPWL) di Puskesmas DKI dengan menggunakan poster. Di dalam poster tersebut juga dimuat logo Lembaga lain yang bekerja sama dengan Kemenkes, yaitu Kementrian Sosial Republik Indonesia dan Badan Narkotika Nasional.

Namun kabarnya program ini dianggap gagal oleh media, karena beberapa faktor seperti kekurangan dokter yang kompeten, sosisalisasinya yang kurang, serta sangat sedikitnya minat dari para pecandu narkotika maupun masyarakat yang ingin melaporkan anggota keluarganya untuk dapat menjalani rehabilitasi dipuskesmas.

Adapun contoh poster yang diteliti dalam penelitian ini adalah yang ditunjukan oleh gambar berikut ini:

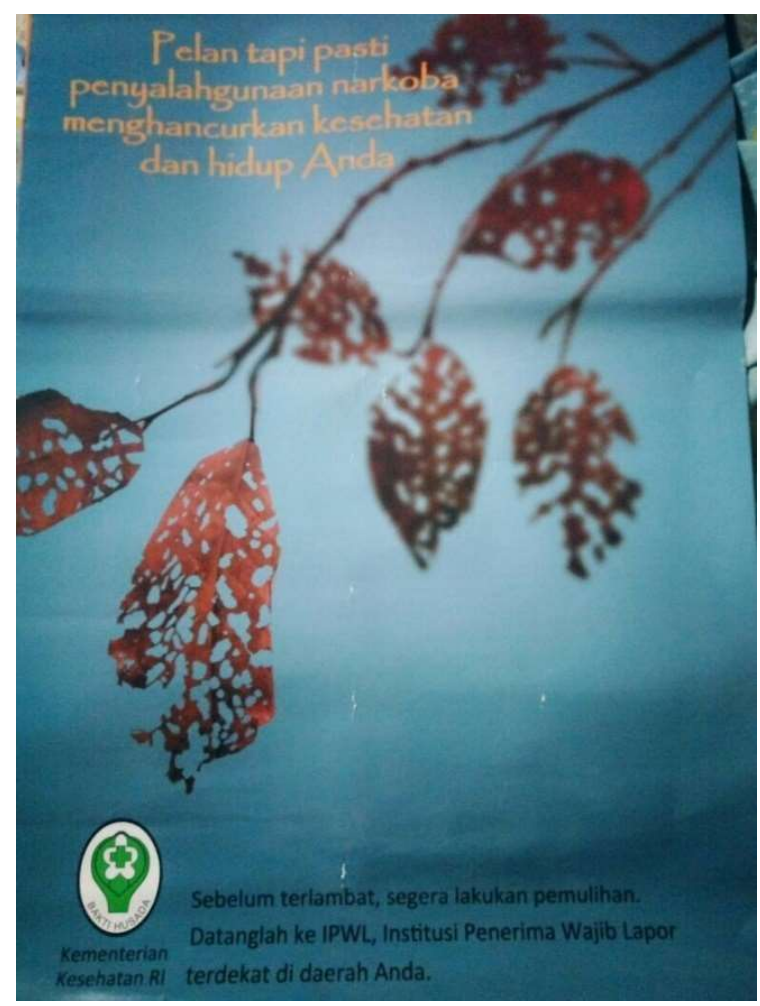

Gambar. 1. Poster IPWL 
Poster di atas, adalah salah satu cara yang dilakukan oleh humas Kemenkes untuk menyampaikan informasi-informasi terbaru mengenai kebijakan dan program-program yang dibuat oleh Kemenkes RI kepada khalayaknya, yaitu seluruh masyarakat Indonesia. Poster merupakan salah satu media publikasi kehumasan.

Humas Kemenkes RI, dalam program IPWL, berusaha menjalankan perannya sebagai Public Relations yang memiliki tugas memberikan informasi (informing), mendidik, dan menyebarluaskan pengetahuan yang benar, sesuai arahan dan kebijakan yang sudah disusun pemerintah dengan melibatkan seluruh stakeholder terkait.

Humas Kemenkes RI, melalui program IPWL bertugas memberikan informasi kepada publik atau masyarakat yang menjadi target dan sasaran organisasinya. Dalam hal salah satu tujuannya adalah agar masyarakat ikut berpartisipasi dalam program IPWL yang dibuat oleh Kemenkes RI.

Untuk mencapai tujuan program IPWL, makan humas kemenkes RI membuat sejumlah Publikasi. Publikasi merupakan perangkat yang sangat penting bagi instansi pemerintahan. Hal tersebut dikarenakan, dengan adanya publikasi yang tepat, maka program dari instansi pemerintahan, dapat menimbulkan efek positif bagi khalayak yang menjadi target dan sasarannya, baik yang ada di dalam, maupun di sekitar lingkungan Kemenkes RI.

Hanya saja, untuk menggunakan media publikasi yang tepat, menjadi persoalan humas Kemenkes RI. Walaupun pada dasarnya, semua jenis publikasi dalam bentuk apapun, sangatlah membantu pekerjaan seorang humas di instansi pemerintahan. Terlebih lagi, ketika proses publikasi itu berjalan, dan dapat terlaksana dengan baik.

Menurut Susilana dkk (2010), dalam sebuah kegiatan publikasi, memerlukan alat atau media utama, yang digunakan untuk menyampaikan informasi kepada khalayaknya. Walaupun pada dasarnya, media adalah segala bentuk dan saluran yang digunakan untuk menyampaikan informasi atau pesan. Dan dalam pengertian lainnya, media adalah alat atau sarana yang digunakan untuk menyampaikan pesan dari komunikator kepada masyarakat.

Dalam penelitian ini, humas Kemenkes RI, membuat sejumlah media sebagai sarana publikasi mengenai Program Institusi Penerima Wajib Lapor (IPWL) di sejumlah Puskesmas di DKI Jakarta. Dalam menjalankan program tersebut, ternyata Kemenkes RI tidak melakukannya sendiri. Tapi juga menjalin sejumlah kerjasama dengan Lembaga pemerintah lainnya. Hal tersebut 
terlihat di dalam publikasi program IPWL yang menggunakan poster. Adapaun Lembaga yang bekerjasama dengan Kemenkes RI antara lain adalah Kementrian Sosial Republik Indonesia, Badan Narkotika Nasional serta puskesmas-puskesmas di wilayah DKI Jakarta yang menjadi mitra Kementrian Kesehatan Republik Indonesia. Semua lembaa pemerintah tersebut bekerjasama untuk mempublikasikan program IPWL kepada masyarakat melalui poster.

Untuk itu meneliti efektivitas poster IPWL tersebut, penelitian ini membuat 33 item pernyataan yang bertujuan mencari tahu pendapat warga disekitar puskesmas kecamatan Senen, mengenai tujuan publikasi program IPWL yang termuat dalam poster.

Pernyataaan pertama, menanyakan tanggapan warga terhadap antusiasme mereka dalam menanggapi poster IPWL. Hasilnya, diperoleh hasil rata-rata, bahwa responden kurang antusias dalam menanggapi poster IPWL, di Puskesmas Kecamatan Senen. Hal tersebut menunjukan bahwa warga sebetulnya kurang tertarik terhadap publikasi IPWL yang terdapat di Puskesmas Kecamatan Senen.

Pernyataan kedua menanyakan pernyataan warga mengenai dukungan mereka terhadap program IPWL. Hasilnya adalah rata - rata responden ragu-ragu untuk mendukung adanya program IPWL. Hal ini menunjukan bahwa warga RT 06/ RW 01, Kelurahan Kenari, Kecamatan Senen, Jakarta Pusat belum tentu mendukung, atapun kurang mendukung adanya program IPWL. Keraguan tersebut, merupakan dampak dari kurang antusiasnya warga terhadap pesan yang disampaikan pada poster IPWL yang terpampang di Puskesmas Kecamatan Senen.

Pernyataan ketiga adalah mengenai pemahaman warga dalam memahami tujuan publikasi, yang terdapat dalam poster IPWL. Hasilnya adalah, rata - rata responden menjawab ragu-ragu dalam memahami tujuan program IPWL yang ditermuat di dalam poster. Hal ini menunjukan bahwa warga RT 06/ RW 01, Kelurahan Kenari, Kecamatan Senen, senada dalam mendukung dan memahami porgam IPWL, yaitu ragu-ragu.

Dari dua pernyataan mengenai dukungan warga terhadap program IPWL dan pemahaman warga dalam memahami tujuan IPWL yang ragu-ragu, menunjukan bahwa poster IPWL belum dapat mempersuasi warga untuk mendukung program IPWL. Diantaranya karena sebagian warga kurang memahami tujuan dari diadakannya program IPWL di Puskesmas Kecamatan Senen, yang merupakan program pemerintah untuk menjaga wilayah lingkungan tempat tinggal mereka dari bahaya penggunaan obat-obat terlaranag alias narkoba. 
Pernyataan keempat adalah, mengenai minat warga terhadap IPWL. Hasilnya adalah ratarata responden yang tidak berminat terhadap program IPWL yang di publikasikan melalui poster.

Minimnya minat warga untuk mengikuti program IPWL ini, merupakan imbas dari tiga pernyataan sebelumnya. Pertama, warga kurang antusias menanggapi poster IPWL. Kedua, warga ragu untuk mendukung program IPWL. Ketiga, warga ragu untuk memahami tujuan program IPWL. Sehingga pada pernyataan tentang minat terhadap program IPWL, warga tidak berminat.

Pernyataan kelima adalah mengenai pendapat warga tentang pesan persuasif pada poster. Hasilnya adalah, rata- rata responden ragu-ragu, terhadap isi pesan persuasif yang terdapat di dalam poster. Hal ini menunjukan, bahwa isi pesan dari poster program IPWL, yang ada di Puskesmas Kecamatan Senen belum persuasif, atau kurang mempersuasi warga.

Keraguan warga terhadap isi pesan pada poster IPWL, merupakan imbas dari kurang antusiasnya mereka terhadap poster IPWL, sehingga memunculkan keraguan-keraguan terhadap dukungan, tujuan, dan isi pesan yang dimuat di dalam poseter IPWL.

Pernyataan keenam adalah, isi pesan pada poster, apakah sudah ditujukan untuk seluruh warga. Hasilnya adalah, rata - rata responden yang tidak setuju bahwa poster program IPWL ditujukan untuk seluruh warga. Hal tersebut dikarenakan ini sejalan dengan pernyataan kurangnya antusias warga terhadap program IPWL yang di publikasikan melalui poster di Puskesmas Kecamatan Senen.

Selain melahirkan keraguan warga untuk memberikan dukungan terhadap program IPWL, warga juga ragu terhadap tujuan dibuatnya program tujuan IPWL, dan warga juga ragu terhadap isi pesan pada poster. Keraguan tersebut kemudian memunculkan pendapat mayoritas warga yang tidak setuju bahwa program IPWL ditujukan untuk seluruh warga.

Pernyataan ketujuh adalah tentang kepercayaan warga terhadap program IPWL. Hasilnya adalah rata - rata responden percaya terhadap program IPWL yang dipublikasikan melalui poster. Namun isi poster IPWL, masih mendapatkan kepercayaan, bahwa program IPWL adalah program resmi yang dibuat oleh pemerintah dan khsusunya dijalankan oleh Kemekes RI.

Pernyataan kedelapan tentang kepuasan warga kerhadap informasi yang terdapat dalam poster IPWL. Hasilnya adalah rata - rata responden puas terhadap informasi yang ada dalam poster IPWL. Kepercayaan warga terhadap program IPWL sebagai program resmi pemerintah yang dijalankan oleh Kemenkes RI di Puskesmas Kecamatan Senen, membuahkan kepuasan warga terhadap informasi yang tertulis di dalam poster. 
Pernyataan kesembilan adalah tentang loyalitas warga terhadap program IPWL. Hasilnya adalah rata - rata responden ragu-ragu untuk bersikap loyal terhadap program IPWL. Walaupun ada kepuasan informasi dan kepercayaan warga, terhadap program IPWL merupakan program resmi pemerintah, yang dijalankan oleh Kemenkes RI, namun tidak serta merta, warga menjadi loyal untuk menjalankan program IPWL. Hal tersebut berkorelasi dengan pernyataan ke empat, dimana warga tidak berminat terhadap program IPWL. Oleh karena itu, tanpa minat dan ditambahkan keraguan warga untuk pendukung program IPWL, maka sudah dipastikan warga juga ragu untuk menberikan loyalitasnya kepada program IPWL di Puskesmas Kecamatan Senen.

Pernyataan kesepuluh adalah tentang netralitas informasi yang terdapat dalam poster IPWL. Hasilnya adalah rata - rata responden setuju bahwa informasi mengenai program IPWL yang dipublikasikan melalui poster tidak mementingkan kepentingan salah satu pihak. Jawaban ini berkorelasi dengan pernyataan bahwa warga percaya program IPWL adalah program resmi pemerintah yang dijalankan oleh Kemenkes RI melalui Puskesmas.

Pernyataan kesebelas adalah tentang program IPWL untuk kepentingan umum. Hasilnya adalah rata - rata responden ragu-ragu bahwa program IPWL dibuat untuk kepentingan umum. Jawaban ini berkorelasi dengan bentuk dukungan warga, yang masih ragu-ragu untuk memberikan dukungan dan loyalitasnya, terhadap program IPWL.

Walaupun mayoritas warga percaya, program IPWL ini, merupakan program resmi pemerintah, tapi mereka ragu, bahwa tujuan program IPWL dibuat untuk kepentingan umum. Hal tersebut dipicu, dari keraguan mereka, terhadap tujuan dibuatnya program IPWL oleh Pemerintah, yang dijalankan oleh Kemenkes RI.

Pernyataan kedua belas adalah tentang pendapat warga mengenai Program IPWL telah berjalan sesuai aturan. Hasilnya adalah rata-rata responden ragu-ragu bahwa program IPWL yang berjalan sesuai aturan. Hal ini menunjukan bahwa menurut mayoritas warga RT 06/ RW 01, Kelurahan Kenari, Kecamatan Senen, Jakarta Pusat, program IPWL belum tentu berjalan sesuai aturan, karena belum teratur dan terorganisir dengan baik.

Keraguan warga terhadap program IPWL telah berjalan sesuai aturan, berkorelasi dengan jawaban mengenai keraguan warga terhadap dukungan dan loyalitas warga terhadap program IPWL ini. Warga ragu bahwa tujuan program IPWL ini ditujukan untuk kepentingan umum, sehingga mereka pun sama ragunya untuk menilai bahwa program IPWL sudah berjalan sesuai 
dengan aturan yang terdapat dalam juknis atau SOP mengenai pelaksanaan program IPWL ini di Puskesmas Kecamatan Senen.

Pernyataan ketiga belas adalah tentang pemahaman warga mengenai tujuan program IPWL, berdasarkan informasi yang terdapat di dalam poster. Hasilnya adalah rata - rata responden memahami tujuan program IPWL. Walaupun mayoritas warga ragu terhadap tujuan dibuatnya program IPWL ini, namun mereka dapat memahami apa yang menjadi tujuan dari progam IPWL. Namun pemahaman tersebut tidak membuat mereka dengan sukarela memberikan dukungan atau sikap loyalnya terhadap program IPWL di Puskesmas Kecamatan Senen.

Pernyataan keempat belas adalah tentang penerimaan warga terhadap program IPWL. Hasilnya adalah rata - rata 3,82 responden menerima program IPWL. Jawaban ini menunjukan tidak ada korelasi antara penerimaan warga terhadap sebuah program pemerintah dengan antusiasme warga dalam memberikan dukungan dan sikap mereka terhadap program tersebut. Banyak faktor yang menyebabkan hal tersebut.

Beberapa faktor tersebut, dapat ditemukan dalam hasil temuan dalam penelitian ini. Faktor pertama adalah penerimaan warga akan sebuah porgam, belum tentu diikuti oleh antusiasme warga. Faktor Kedua, warga yang kurang antusias, akan ragu untuk memberikan dukungan. Faktor Ketiga, warga yang ragu dalam memberikan dukungannya terhadap sebuah program, juga akan ragu untuk memberikan loyalitasnya. Faktor keempat, dampat dari ketiga faktor sebelumnya, menyebabkan tidaknya berminatnya warga terhadap program IPWL ini. Berdasarkan paparan tersebut, peneliti mendapatkan gambaran, antara faktor satu dengan lainnya, terdapat hubungan korelasi, atau hubungan sebab akibat.

Pernyataan kelima belas adalah mengenai tanggapan warga terhadap aturan wajib lapor di dalam program IPWL. Hasilnya adalah rata - rata responden ragu-ragu terhadap aturan wajib lapor di dalam program IPWL. Lagi-lagi, keraguan tersebut juga disebabkan oleh empat faktor yang sudah dipaparkan dalam paragraph sebelumnya. Akibat keraguan warga untuk memberikan dukungan dan sikap loyal, maka mereka pun ragu untuk melaporkan kepada petugas IPWL di Puskesmas, bila mereka mengetahui, ada warga di sekitar lingkungan tempat tinggal mereka, yang memerlukan bantuan rehabilitasi.

Pernyataan keenam belas adalah tentang kepedulian warga terhadap IPWL. Hasilnya adalah rata - rata responden setuju bahwa program IPWL bertujuan untuk menumbuhkan rasa saling peduli terhadap sesama warga. Sikap saling peduli antar warga satu sama lain, dapat 
menciptakan kondisi yang kondusif dan nyaman, bagi berlangsungnya program IPWL di Puskesmas Kecamatan Senen.

Jawaban di atas, berkorelasi dari kepercayaan masyarakat terhadap program IPWL sebagai program resmi dari pemerintah. Sehingga mereka pun percaya bahwa program IPWL memiliki tujuan yang baik. Salah satunya, program IPWL bertujuan untuk menumbuhkan rasa saling peduli terhadap sesama warga, khususnya warga yang memerlukan bantuan rehabilitasi di IPWL, Puskesmas Kecamatan Senen.

Pernyataan ketujuh belas adalah, tentang tanggapan warga mengenai IPWL menimbulkan sikap damai. Hasilnya adalah, rata - rata responden ragu-ragu, program IPWL menimbulkan sikap damai. Hal ini menunjukan, bahwa menurut responden program IPWL belum tentu, dapat menimbulkan sikap damai, berupa persatuan dan kesatuan antar warga.

Jawaban di atas, menjadi kontraproduktif dengan jawaban terhadap pernyataan sebelumnya. Di satu sisi, warga memahami, bahwa tujuan dari diadakan program IPWL dari pemerintah, adalah untuk menumbuhkan rasa saling peduli di kalangan warga satu sama lain. Namun warga ragu terhadap implementasinya. Menurut mayoritas warga, saat aturan IPWL di implementasikan, justru yang terjadi bukan menimbulkan sikap damai, tapi justru sebaliknya.

Pernyataan kedelapan belas adalah, tentang program IPWL menciptakan nilai hak asasi manusia. Hasilnya adalah rata - rata responden setuju bahwa program IPWL menciptakan nilai hak asasi manusia, khususnya bagi warga RT 06/ RW 01, Kelurahan Kenari, Kecamatan Senen, Jakarta Pusat. Warga mendapatkan hak nya masing-masing sesuai apa yang seharusnya ia dapat.

Jawaban ini berkorelasi dengan jawaban warga yang setuju dan memahami bahwa program IPWL bertujuan dapat menumbuhkan rasa saling peduli terhadap sesama warga. Mereka pun juga setuju bahwa program IPWL dapat menciptakan nilai-nilai hak asasi manusia. Namun kesetujuan ini hanya pada tahap pengetahuan bahwa program IPWL pada dasarnya bertujuan baik. Tapi untuk warga memberikan dukungan dan sikap loyal, berada pada sisi yang lainnya.

Pernyataan kesembilan belas adalah, mengenai poster program IPWL, mampu menyakinkan warga untuk ikut berpartisipasi dalam program IPWL. Hasilnya adalah rata - rata responden ragu-ragu. Lahi-lagi jawaban ini memantapkan keraguan warga, dalam memberikan minat mereka untuk ikut berparsipasi, memberikan dukungan, dan bersikap loyal terhadap program IPWL. Salah satu pemicunya adalah, keraguan mereka, bahwa program ini akan menimbulkan sikap damai. 
Pernyataan kedua puluh adalah mengenai pendapat warga mengenai manfaat IPWL. Hasilnya adalah rata-rata responden setuju bahwa program IPWL bermanfaat. Walaupun warga memahami bahwa tujuan program IPWL baik, seperti dapat menumbuhkan sikap saling peduli, dan sesuai dengan HAM, serta kini ditambah dengan satu alasan lain, yaitu bermanfaat. Namun warga melihat, besarnya resiko yang akan mereka terima, jika mereka terlibat aktif dalam memberikan dukungan dan sikap loyal mereka terhadap program IPWL.

Pernyataan kedua puluh satu adalah, tentang kalimat dalam poster program IPWL, sudah tepat untuk mempersuasif orang, agar ikut berpartisipasi. Hasilnya adalah rata-rata responden setuju dengan kalimat dalam poster program IPWL tepat untuk mempersuasif orang agar ikut berpartisipasi. Secara teknis, warga tidak melihat ada masalah dalam pesan yang tertulis pada poster IPWL. Menurut mereka, pesan yang tertulis pada poster sudah memuat kalimat yang tepapt untuk mempersuasi warga agar terlibat dan berpartisipasi dalam program IPWL.

Pernyataan kedua puluh dua, mengenai poster program IPWL, menimbulkan rasa saling peduli terhadap sesama warga. Hasilnya adalah rata - rata responden setuju poster program IPWL menimbulkan rasa saling peduli terhadap sesama warga. Penyataan ini hampir mirip dengan program IPWL dapat menumbuhkan rasa saling pedulu antara satu warga dengan warga lainnya. Hanya saja, timbul dan tumbuh adalah dua kata yang berbeda maknanya. Timbul adalah sesuatu yang baru saja muncul, sedangkan tumbuh, sesuatu yang sudah timbul, tapi ingin disemarakan lagi atau ditingkatkan lagi jumlahnya.

Pernyataaan kedua puluh tiga adalah, program IPWL tidak memuat unsur diskriminasi antar warga. Hasilnya adalah rata-rata responden ragu-ragu, program IPWL tidak memuat unsur diskriminasi antar warga. Sebagian warga menilai masih ada unsur diskrimasi terhadap pasien program IPWL. Keraguan ini muncul, karena mayoritas warga menilai, bahwa program IPWL ini, dibuat tidak ditujukan untuk seluruh warga. Selain itu, di dalam pelaksanaannya, terdapat proses yang dirasakan warga, sebagai tindakan yang diskriminatif.

Pernyataan kedua puluh empat adalah, program IPWL menciptakan rasa saling menghargai antar sesama. Hasilnya adalah, rata-rata responden setuju, program IPWL menciptakan rasa saling menghargai antar sesama. Meskipun masyarakat terdiri dari beragam golongan, yan terdiri dari SARA yang berbeda, namun menruut mayoritas warga, program IPWL dianggap dapat menghargai perbedaan tersebut. Jawaban ini berkorelasi dengan pernyataan mengenai, poster IPWL menimbulkan rasa saling peduli terhadap sesama warga. 
Pernyataan kedua puluh lima adalah, pesan yang disampaikan melalui poster program IPWL, benar adanya. Hasilnya adalah, rata-rata responden sangat setuju pesan yang disampaikan melalui poster program IPWL benar adanya. Warga tidak merasa dibohongi, sehingga kredibilitas Kemenkes baik dimata publik. Pernyataan ini berkorelasi dengan pernyataan, bahwa mayoritas warga percaya, bahwa IPWL ini merupakan program resmi pemerintah, yang dijalankan oleh Kemenkes RI, di Puskesmas Kecamatan Senen

Pernyataan kedua puluh enam adalah, informasi dari poster program IPWL, melalui sumber yang terpercaya. Hasilnya adalah, rata-rata responden sangat setuju, Informasi dari poster program IPWL melalui sumber yang terpercaya. Lagi-lagi jawaban tersebut, mempertegas pernyataan sebelumnya, mengenai kredibilitas sumber, yaitu Kemenkes RI. Mayoritas warga sangat percaya, bahwa program ini program resmi pemerintah, yang dibuatkan posternya, dan posternya pun di pasang di lembaga pemerintah yang memiliki kewenangan untuk menjalankan program tersebut, yaitu Puskesmas Kecamatan Senen.

Pernyataan kedua puluh tujuh adalah, poster program IPWL membuat warga percaya tentang program IPWL. Hasilnya adalah rat-rata responden setuju, poster program IPWL membuat warga percaya tentang program IPWL. Jawaban tersebut, memperteguh tiga pernyataan sebelumnya mengenai kepercayaan warga terhadap sumber, program dan isi pesan pada poster IPWL.

Pernyataan kedua puluh delapan adalah, tentang program IPWL bersifat terbuka untuk masyarakat umum. Hasilnya adalah, rata-rata responden setuju, program IPWL bersifat terbuka, untuk masyarakat umum, karena informasi yang didapat jelas, dan sesuai dengan apa yang diinformasikan. Walaupun pada pernyataan kedua puluh tiga, warga masih ragu bahwa program IPWL tidak memuat unsur diskriminasi, tapi warga setuju bahwa program ini adalah program yang terbuka untuk seluruh warga setempat.

Pernyatan kedua puluh delapan ini juga kontra produktif dengan pernyataan kesebelas, dimana mayoritas warga ragu-ragu akan tujuan dari dibuatnya program IPWL untuk kepentingan umum. Mayoritas warga hanya setuju, bahwa program IPWL merupakan program yang terbuka untuk seluruh warga setempat, namun hal tersebut tetap saja tidak menjadikan warga setuju bahwa tujuan dibuatnya program IPWL untuk kepentingan umum. Hal tersebut dikarenakan sikap masyarakat yang skeptis dan kritis terhadap program yang dibuat pemerintah, termasuk program IPWL. 
Pernyataan kedua puluh sembilan adalah, tentang pesan yang disampaikan melalui poster program IPWL selalu sama. Hasilnya adalah, rata-rata responden sangat setuju pesan yang disampaikan melalui poster program IPWL selalu sama, karena pesan yang disampaikan di beberapa poster memuat pesan yag konsisten dan tidak berubah-ubah kalimatnya.

Pernyataan ketiga puluh adalah, isi dalam poster program IPWL bersifat umum. Hasilnya adalah, rata-rata responden setuju, Isi dalam poster program IPWL, bersifat umum, karena informasi yang tertulis dapat dibaca dengan jelas, dan sesuai dengan apa yang di informasikan secara umum kepada masyarakat umum.

Pernyataan ketiga puluh satu adalah, program IPWL dibuat berdasarkan riset dilapangan, tentang bahaya obat-obatan terlarang. Hasilnya adalah, rata-rata responden setuju, program IPWL dibuat berdasarkan riset dilapangan, tentang bahaya obat-obatan terlarang. Jawaban ini lagi-lagi, tidak berkorelasi dengan dukungan dan sikap loyal warga terhadap program IPWL. Walaupun mayoritas warga setuju bahwa program IPWL disusun karena Kemenkes sudah melakukan kajian berdasrakan riset di lapangan tentang bahaya obat-obatan terlarang, namun masyarakat kurang antusias terhadap program IPWL. Bahkan mayoritas warga ragu terhadap isi pesan persuasifnya, terutama yang akan menimbulkan sikap damai di kalangan warga pasca adanya aduan kepada petugas IPWL di Puskesmas Kecamatan Senen.

Pernyataan ketiga puluh dua adalah, program IPWL berisikan seruan, dari dampak bahayanya penyalahgunaan obat-obatan terlarang. Hasilnya adalah, rata-rata responden setuju, program IPWL berisikan seruan yang ditujukan untuk warga, terhadap dampak dan bahaya, yang akan dialami warga, akibat dari penyalahgunaan obat-obatan terlarang. Sama seperti analisis sebelumnya, walaupun warga setuju bahwa program IPWL adalah sebuah seruan atau ajakan kepada warga untuk berperan atau berpartisipasi aktif pada program IPWL, namun tidak berarti mereka lantas memberikan dukungan dan loyalitasnya.

Pernyataan ketiga puluh tiga adalah isi dari poster program IPWL selalu up to date. Hasilnya adalah rata - rata responden setuju dengan isi poster yang memuat informasi yang aktual. Jawaban ini juga memuat analisis yang mirip dengan analisis sebelumnya, walaupun poster IPWL berisikan informasi yang actual seputar narkoba, namun tidak berdampak terhadap minat warga untuk memberikan dukungan dan sikap loyal terhadap program IPWL. Bahkan mayoritas warga menjawab tidak berminat terhadap program IPWL ini. 
Dari tiga puluh tiga pernyataan di atas, maka di dapatkan nilai mean per dimensi dalam penelitian ini. Berikut ini adalah hasil mean tersebut yang disajikan di dalam gambar 1.

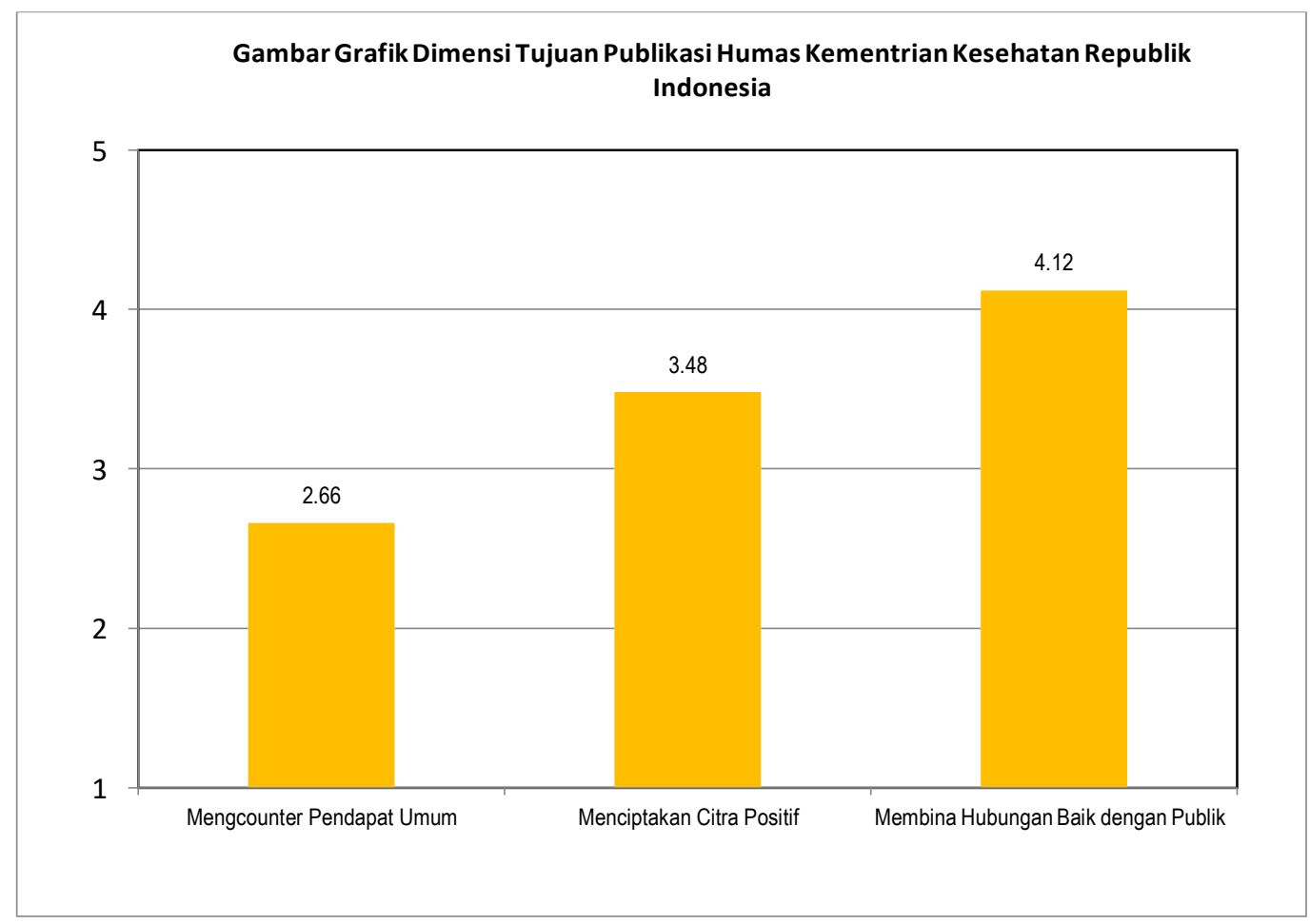

Gambar 1. Mean per Dimensi

Dari ketiga dimensi tersebut, dimensi membina hubungan baik dengan publik merupakan dimensi tertinggi. Hal tersebut disebabkan, annggapan warga bahwa humas Kemenkes RI sudah tepat dalam membina hubungan baik dengan publik. Sedangkan dimensi mengcounter pendapat umum memperoleh nilai mean terendah. Hal tersebut disebabkan, warga menilai Kemenkes RI belum maksimal dalam memberikan feedback atas berbagai pendapat umum dari publik. Gambar 2 menyajikan olahan hasil mean per indikator dalam penelitian ini. 


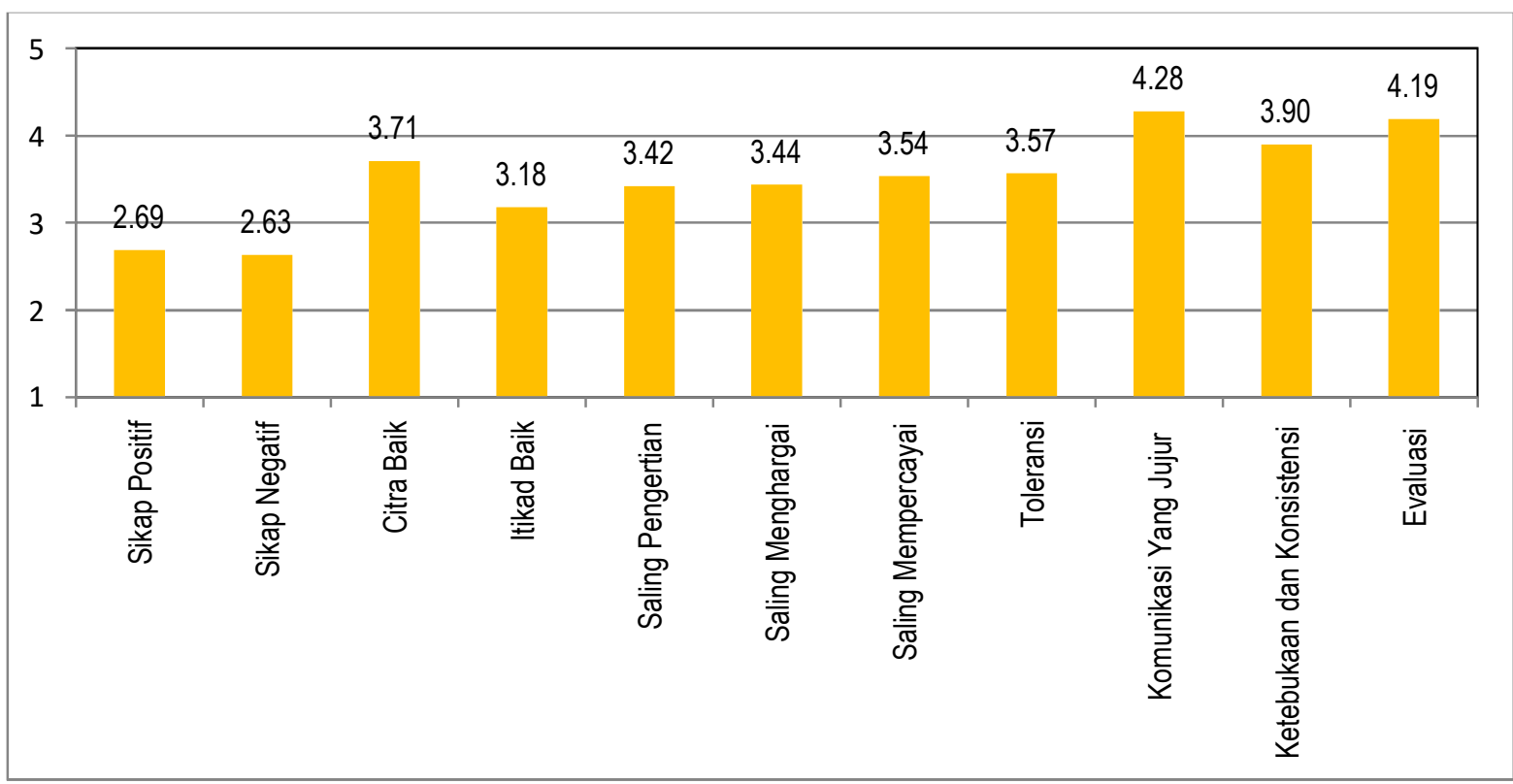

Gambar 2. Mean per Indikator

Gambar 2 adalah hasil pengolahan data dari mean per indikator dalam penelitian ini. Terlihat bahwa mean tertinggi berada pada indikator komunikasi yang jujur. Hal tersebut menunjukan bahwa Kemenkes RI sudah melakukan komunikasi yang jujur di dalam poster program Instansi Penerima Wajib Lapor (IPWL) di Puskesmas Kecamatan Senen. Berikut ini paparan singkat tiga indikator tertinggi, yang diurutkan dari indikator tertinggi.

Indikator pertama yaitu komunikasi yang jujur. Warga menilai humas Kemenkes RI sudah menyampaikan pesan secara jujur melalui poster program IPWL. Indikator kedua adalah keterbukaan dan konsistensi. Warga setuju bahwa program IPWL adalah program yang memberikan informasi yang terbuka dan konsisten pada poster. Indikator ketiga yaitu evaluasi. Warga setuju bahwa Program IPWL dibuat setelah mencari tahu kekurangan dari program serupa, yang sudah dijalankan.

Sementara itu, indikator terendah adalah sikap negatif. Sikap negatif sebagai indikator terendah, juga merupakan respon positif untuk program IPWL Kemenkes RI. Warga masyarakat yang menjadi responden dalam penelitian ini, yaitu warga RT 06/ RW 01, Kelurahan Kenari, Kecamatan Senen Jakarta Pusat, berpendapat bahwa program IPWL sudah baik, karena mereka percaya terhadap program IPWL yang dipublikasikan melalui poster. Hanya saja mereka masih memiliki banyak keraguan terhadap program IPWL, sehingga hal tersebut berimbas kepada kurangnya antusias warga terhadap program IPWL di Puskesmas Kecamatan Senen. 
Selain itu, keraguan warga, juga tampak pada keraguan mereka untuk mendukung program IPWL. Hal tersebut disebabkan oleh beberapa faktor, seperti keraguan warga dalam memahami tujuan program IPWL yang ditermuat di dalam poster. Hal tersebut kemudian berimbas kepada minat warga, yang minim terhadap program IPWL.

Keraguan warga yang lain adalah, pada pesan persuasif yang ada pada poster. Mayoritas warga RT 06/ RW 01, Kelurahan Kenari, Kecamatan Senen, Jakarta Pusat, yang menjadi responden dalam penelitian ini, memiliki keragu-raguan terhadap isi pesan persuasif di dalam poster. Menurut mayoritas mereka, isi pesan pada poster belum ditujukan untuk seluruh warga. Hal tersebut kemudian berimbas, kepada loyalitas warga terhadap program IPWL. Mereka ragu untuk bersikap loyal terhadap program IPWL.

Sejumlah keraguan warga di atas, mengenai program IPWL, menjadi pekerjaan rumah untuk humas Kemenkes RI untuk mempersuasi warga, agar dapat mewujudkan tujuan dibuatnya program IPWL, khususnya sesuai dengan tujuan publikasi program IPWL.

Bukan hanya persoalan di SDM saja yang dirasakan, tapi juga pesan publikasi yang tersampaikan kepada warga masih banyak diragukan warga, terutama untuk mendukung apalagi menjadi loyal. Padahal permasalahan seputar narkoba di wilayah DKI Jakarta sangat Marak. Sayangnya data ter up date, juga tidak bisa diberikan oleh humas Kemenkes kepada peneliti, dengan alasan tidak terdapat MOU antara institusi untuk mempublikasikan dalam penelitian ini.

\section{SIMPULAN}

Tujuan publikasi humas Kementrian Kesehatan Republik Indonesia, sudah baik dalam hal membina hubungan baik dengan publik, namun belum maksimal dalam hal mengcounter pendapat umum.

Dimensi ketiga, membina hubungan baik dengan publik menjadi dimensi dengan rata-rata tertinggi. Hal tersebut karena warga merasa humas Kemenkes RI sudah baik, dalam hal membina hubungan baik dengan publik. Kehadiran poster program Institusi Penerima Wajib Lapor (IPWL) di Puskesmas Kecamatan Senen, dinilai responden sebagai usaha untuk membina hubungan baik dengan publik. Kemenkes RI melakukan usaha membina hubungan baik dengan publik, dengan cara memberikan infomasi yang tepat sasaran, yaitu masyarakat yang ingin melakukan rehabilitasi akibar terpapar narkoba. 
Namun pada dimensi ketiga ini, indikator keterbukaan dan konsistensi menjadi indikator dengan mean terendah dalam dimensi ini. Responden menilai informasi yang terdapat pada poster, belum sepenuhnya memberikan informasi yang terbuka kepada publik. Selain itu pesan yang disampaikan di beberapa poster mengenai IPWL, dinilai cenderung tidak konsisten. Walaupun banyak juga poster yang memuat kata-kata yang konsisten.

Dimensi pertama, mengcounter pendapat umum menjadi dimensi yang terendah dalam penelitian ini. Hal tersebut karena, warga merasa bahwa humas Kementrian Kesehatan Republik Indonesia masih kurang mensosialisasikan isi poster yang menjelaskan mengenai program Institusi Penerima Wajib Lapor (IPWL) kepada warga. Hal inilah yang memicu rendahnya kesadaran warga untuk terlibat aktif dalam program IPWL ini. Warga merasa humas Kemenkes RI kurang melakukan sosialisasi, bahwa di Puskesmas Kecamatan Senen, dibuka unit khusus yang menangani masyarakat yang terpapar narkoba. Padahal, banyak warga yang tinggal di Kawasan Senen yang terpapar narkoba, tapi tidak mengetahui adanya program IPWL di Puskesmas mereka. Untuk itu, diharapkan Humas Kemenkes RI menambah kegiatan sosisalisasi program IPWL di setiap lingkungan, khsussnya lingkungan yang berada di sekitar puskesmas yang terdapat program rehabilitasi IPWL. Hal tersebut bertujuan agar masyarakat lebih tahu perihal IPWL dan juga menyebarluaskan informasi bahwa program tersebut masih berjalan di puskesmas tersebut. Minimnya informasi tersebut, berimbas pada jumlah pasien yang dating ke puskesmas kecamatan senen. Umumnya warga disana, kurang menyadari pentingnya rehabilitasi untuk warga yang terpapar narkoba. Mereka umumnya cuek, dengan keadaan sekitar dan lebih memilih untuk bersikap individualitis untuk masalah narkoba di lingkungan tempat tinggal mereka.

Humas Kemenkes juga diharapkan tidak hanya menggunakan media poster sebagai bentuk publikasinya, namun juga aktif menggunakan media, baik itu radio, atau iklan di televisi, yang memberitahukan bahwa program IPWL sudah dijalankan, di berbagai puskesmas, serta rumah sakit khususnya di DKI Jakarta, serta memanfaatkan teknologi terkini dalam menyampaikan tujuan publikasinya, seperti menggunakan Instagram atau Fecebook untuk penyebaran poster IPWL.

\section{DAFTAR PUSTAKA}


Ardianto, Elvinaro. (2013). Handbook of Public Relations Pengantar Komprehensif. Bandung: Simbiosa Rekatama Media.

Darwis, Riadi, Rr Adi Hendraningrum, dan Joko Prayitno. (2015). Penggunaan Bahasa Publisitas Program Kegiatan Pemerintah Daerah Tingkat II Bandung. Jurnal Kajian Bahasa dan Pariwisata, 2 (2) 2002015

Gani, Husni Abdul, Erdi Istiaji, dan Atdelia Irla Kusuma. (2014). Perbedaan Efektivitas Leaflet dan Poster Produk Komisi Penanggulangan AIDS Kabupaten Jember Dalam Perilaku Pencegahan HIV/AIDS. Jurnal IKESMA 10 (1) 31-48

Malhotra, Naresh K. (2010). Marketing Research: Sixth Edition. New Jersey: Pearson Education.

Neuman, W. Lawrence. (2011). Social Research Methods: Seventh Edition. Boston: Person Education.

Program IPWL di Puskesmas DKI Gagal. (2017, 15 September), diakses dari html://news.metrotvnews.com/metro/Rb1OPo3K-program-ipwl-di-puskesmas-dki-gagal.

Safitri, Dini. (2015). Argument Rhetoric Learning Model in Social Media (Analysis Toulmin Model of Jokowi Political Decision on Facebook). Advanced Science Letter, 21 (7) 2348-2351 (4)

Zainal A, Yusuf. (2015). Metode Penelitian Komunikasi: Penelitian Kuantitatif. Bandung: CV. Pustaka Setia 